\title{
Field apple scab susceptibility of a diverse Malus germplasm collection identifies potential sources of resistance for apple breeding
}

\author{
David Papp ${ }^{1 \dagger}$, Liqiang Gao ${ }^{1,2 \dagger}$, Ranjita Thapa ${ }^{1}$, Dan Olmstead ${ }^{3}$ and Awais Khan ${ }^{1 *}$
}

\begin{abstract}
Background: Breeding for resistance to apple scab (caused by Venturia inaequalis), the most devastating fungal disease of apples, relies on genetic resources maintained in germplasm collections.

Methods: To identify new sources of scab resistance, we evaluated 177 Malus accessions, including 27 primary and 13 hybrid Malus species from diverse geographical origins, in an orchard at Geneva, New York. We also screened a differential host set for 2 years to monitor for changes in the effectiveness of ten known scab resistance genes, which allowed us to confirm the presence of virulent pathogen races in the orchard.

Results: We found that $37 \%$ of the wild Malus accessions and domesticated cultivars were resistant to apple scab in the field. Several of these accessions were unrelated to sources of previously known resistance genes and are promising for apple scab genetic research and resistance breeding. Cultivars carrying the Rvi6 (Vf) gene from Malus floribunda clone 821, e.g. 'Liberty' or 'Florina', remained resistant despite the breakdown of Rvi6. 'Demir', a Malus hybrid from Turkey, and 'Chisel Jersey', a traditional English hard cider cultivar, showed fewer symptoms than the Rvi6 resistant cultivar 'Prima'. Races 1 to 7 and 9 of $V$. inaequalis were present in the orchard, but no scab was observed on the indicator host accessions for races 11 and 12 .

Conclusions: Detailed and systematic screening of Malus germplasm identified resistant and moderately resistant donor accessions based on resistance reaction types. These accessions are promising for use in future genetic studies to identify novel sources of scab resistance alleles for apple breeding to develop cultivars with durable apple scab resistance.
\end{abstract}

Keywords: Venturia inaequalis, Disease resistance, Core collection, Differential hosts

\section{Introduction}

Disease susceptibility of commercial apple cultivars (Malus domestica Borkh.), and the continual emergence of new pathogenic races that overcome resistance genes, are major threats to the apple industry worldwide. Apple scab (causal agent: Venturia inaequalis Cke./Wint.) is the

\footnotetext{
*Correspondence: awais.khan@cornell.edu

${ }^{\dagger}$ David Papp and Liqiang Gao contributed equally to this work

1 Plant Pathology and Plant-Microbe Biology Section, Cornell University, Geneva, NY 14456, USA

Full list of author information is available at the end of the article
}

most devastating fungal disease of apples in humid areas throughout the world where apple is grown (GonzálezDomínguez et al. 2017). The majority of apple cultivars grown commercially in the USA are susceptible to apple scab. Apple scab lesions on fruit mainly impact their cosmetic appearance, severely limiting their marketability. Growers must apply approximately $12-18$ fungicide sprays per growing season to limit quality and yield loss due to apple scab (Peck et al. 2010; MacHardy et al. 2001). Frequent use of fungicides contributes significantly to production costs, and to negative human health and environmental impacts. Apple cultivars resistant

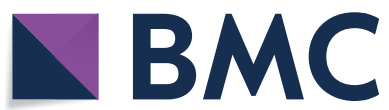

(c) The Author(s) 2020. This article is licensed under a Creative Commons Attribution 4.0 International License, which permits use, sharing, adaptation, distribution and reproduction in any medium or format, as long as you give appropriate credit to the original author(s) and the source, provide a link to the Creative Commons licence, and indicate if changes were made. The images or other third party material in this article are included in the article's Creative Commons licence, unless indicated otherwise in a credit line to the material. If material is not included in the article's Creative Commons licence and your intended use is not permitted by statutory regulation or exceeds the permitted use, you will need to obtain permission directly from the copyright holder. To view a copy of this licence, visit http://creativeco mmons.org/licenses/by/4.0/. The Creative Commons Public Domain Dedication waiver (http://creativecommons.org/publicdomain/ zero/1.0/) applies to the data made available in this article, unless otherwise stated in a credit line to the data. 
to scab require fewer fungicide applications, saving on costs and reducing the environmental impact of disease control (Papp et al. 2019; Brown and Maloney 2008; MacHardy et al. 2001). Malus accessions and land races maintained in the US national germplasm repository are sources of diverse functional alleles that can be used to breed apple cultivars with enhanced and durable resistance (Byrne et al. 2018). In fact, large-scale screening of germplasm repositories is a common strategy to identify valuable traits for use in breeding for many major crop species (Girichev et al. 2018; Liang et al. 2015; Vasudevan et al. 2014). Conventional commercial apple production is driven mainly by desirable fruit quality traits including taste and shelf life, but development of new apple scab resistant, or tolerant, cultivars might allow reduction of disease management costs, fungicide resistance development, as well as reduce negative environmental and health impacts, and is especially critical for organic and low input production (Koutis et al. 2018; Kellerhals et al. 2004). Unfortunately, the introgression of disease resistance alleles from wild sources into apple cultivars with good fruit quality is a slow and challenging process and so the proportion of scab-resistant cultivars in commercial production remains low (Brown and Maloney 2013).

Genetic resistance to scab in apple is primarily guided by major resistance genes, in a classical gene-for-gene relationship with the $A v r$ genes of the pathogen. To date, 20 resistance genes ( $R v i$ genes) have been described in $V$. inaequalis, most of which were identified in wild Malus accessions and landraces (Bus et al. 2011; Khajuria et al. 2018). Only two of the Rvi genes, Rvi6 (receptor kinase gene) and Rvi15 (TIR-NBS-LRR gene) have been characterized and their functionally validated (Schouten et al. 2014; Jansch et al. 2014). Unfortunately, many of the resistance genes, including the well-characterized Rvi6 gene, have been overcome by novel virulent races of the scab pathogen (Papp et al. 2019; Parisi et al. 1993, 2004; Xu et al. 2008). A successful apple scab resistance breeding program in the USA between the Universities of Purdue, Rutgers and Illinois (the PRI initiative), used resistance genes from four sources, $M$. floribunda Sieb. ex Van Houtte clone 821 (Rvi6 and Rvi7) (Japanese crabapple), M. micromalus Makino (Rvi5) (Midget crabapple or Kaido crabapple), M. domestica sel. R12740-7A (Rvi2 and Rvi4), and the common apple 'Antonovka' (Rvi10, Rvi17, polygenic), to develop commercial scabresistant cultivars and pre-breeding materials. These four genotypes became the foundation for later breeding work worldwide (Crosby et al. 1992). However, most modern scab resistant cultivars carry Rvi6 resistance from $M$. floribunda 821 (Brown and Maloney 2013).

Monitoring the virulence of pathogen races, as well as understanding the evolutionary and genetic mechanisms responsible for loss of host resistance, are essential both for managing disease resistance and developing durable resistance (Patocchi et al. 2020). In the USA, races 1 to 5 and 9 of $V$. inaequalis have been previously reported to overcome Rvi1, Rvi5 and Rvi9, respectively (Beckerman et al. 2009; Durham et al. 1999; Hagan et al. 2000; Shay and Williams 1956; Williams and Kuc 1969), but there is no information regarding races of $V$. inaequalis with an ability to cause disease on apple genotypes with Rvi11 and Rvi12 resistance genes (derived from $M$. baccata (L.) Borkh. 'jackii' and 'Hansens baccata \#2'). The presence of races 6 and 7, which can infect M. floribunda 821, was suggested by Beckerman et al. (2009), but was only recently confirmed by characterization of monosporic isolates of $V$. inaequalis collected from $M$. floribunda 821 (Papp et al. 2019). According to the most recent update from monitoring scab resistance of differential indicator cultivars and accessions in 14 countries, the most promising $R$ genes, exhibiting consistent resistance across locations to date, are Rvi5, Rvi11, Rvi12, Rvi14 and Rvi15 (Patocchi et al. 2020).

Screening the existing apple germplasm collections for scab resistance can contribute to the identification of additional scab resistance gene resources, and if utilized, eventually to the development of new resistant cultivars with good fruit quality (Papp et al. 2019). The national Malus collection at the USDA (United States Department of Agriculture) Plant Genetic Resources Unit (PGRU) is the world's largest apple germplasm repository, with 5004 unique Malus accessions growing in the field and 1603 seedlots representing $M$. domestica, 33 Malus species, and 15 hybrid species from around the world (Volk et al. 2015a). Approximately 2500 accessions in the collection have been evaluated for a 28-trait descriptor set (Volk et al. 2015a). The collection exhibits broad diversity for a large range of morphological descriptors (e.g., leaf, shoot, flower and bark characteristics), economically important horticultural traits (e.g., tree vigor, shoot traits, ploidy, flowering, fruiting characteristics), disease and pest resistance, and fruit quality traits (Forsline and Aldwinckle 2001, 2003; Harshman et al. 2017; Hokanson et al. 2001; Jurick et al. 2011; Khan and Chao 2017; Luby et al. 1996, 2002; Momol et al. 1999; Myers et al. 2008; Norelli et al. 2013; https://www.ars-grin.gov).

Comprehensive genetic characterization of the entire USDA-PGRU apple collection for disease resistance is laborious and logistically challenging, especially for disease evaluation in the field. Some wild Malus accessions of the USDA-PGRU collection, particularly $M$. sieversii (Ledeb.) M.Roem. (Aldwinckle et al. 1997; Hokanson et al. 1997; Volk et al. 2005) and M. orientalis Uglitzk. ex Juz. (Volk et al. 2008), have been screened for apple scab resistance, and a considerable number of the accessions 
showed resistance to $V$. inaequalis in those studies. In general, and with the exception of a few specifically bred cultivars, $M$. domestica cultivars show a low level of scab resistance (Aldwinckle et al. 1997; Brown and Maloney 2008, 2013). Development of core collections, representing maximum genetic and trait diversity in the genepool of various crop species, has been widely adopted to lower the maintenance costs and evaluation of crop germplasm (Escribano et al. 2008; Liang et al. 2015; Schoen and Brown 1995). To this end, a core collection of 258 individual Malus accessions, representing genetic diversity of the whole collection, was established at five field locations in the U.S.A. to assess disease resistance, fruit quality, and horticultural traits (Luby et al. 1996; Potts et al. 2012). With regard to disease resistance, the Malus core collection has been evaluated for fire blight resistance in the greenhouse (Khan et al. 2013), but no extensive evaluation has yet been initiated to screen the 258 Malus accessions for resistance to apple scab.

Screening accessions in the field is the most direct method to assess scab resistance relevant to production systems. However, for successful infection with the pathogen, not only are a virulent race of $V$. inaequalis and a susceptible host required, but a favorable environment is also needed, so as to satisfy the host/pathogen/environment interactions (Francl 2001). Particularly humid years are conducive to spore germination (Machardy and Gadoury 1989) and offer an excellent opportunity to identify scab resistance in the field; indeed, the identification of $V f$ resistance occurred in such a season (Crosby et al. 1992). The growing season was wet in 2019, and the resulting favorable weather conditions for development of epidemics of scab may have contributed to the development and occurrence of new races of $V$. inaequalis with the ability to infect the previously resistant $M$. floribunda 821 (Papp et al. 2019).

In this study, firstly, we evaluated the scab resistance of 177 diverse Malus accessions in the field, including wild species, cultivars, and hybrid selections to identify new sources of scab resistance. Secondly, we assessed scab on a differential host set of ten apple genotypes to monitor the breakdown of resistance for each of the ten known scab resistance genes, and also to monitor the presence of virulent pathogen races in the orchard.

\section{Materials and methods \\ Plant material}

The apple scab resistance reaction types of 177 accessions of the Malus core collection were evaluated in the research orchard at Cornell AgriTech, Geneva, New York $\left(42^{\circ} 52^{\prime} 38^{\prime \prime} \mathrm{N}, 77^{\circ} 03^{\prime} 08^{\prime \prime} \mathrm{W}\right)$. The orchard comprises four replicated blocks of the core collection. The core collection is derived from the USA national Malus germplasm repository and includes 27 primary wild Malus species and 13 interspecific hybrid species, 61 domestic apple cultivars/landraces and 36 unspecified hybrid selections (Table 1). Most of the hybrid selections were developed by the PRI Initiative and other breeding programs, or are crabapples of unknown parentage. The 177 accessions represent the major part of a core collection of 258 individual Malus accessions that was established at five field locations in the U.S.A. to evaluate disease resistance, fruit quality, and horticultural traits (Khan et al. 2013; Luby et al. 1996; Potts et al. 2012). Some trees were lost over time at some orchard locations and were not replaced. The unique Plant Introduction (PI) number of each accession used in this study (Table 1) was obtained from the USDA Germplasm Resources Information Network (GRIN) database (https://www. ars-grin.gov), and can be used to compare accessions evaluated in different studies. In addition, the research orchard includes ten differential host accessions with known apple scab resistance genes to identify previously characterized races of $V$. inaequalis. If a differential host was not available as proposed by Bus et al. (2011), alternative hosts (some with more than one $R$ gene) present in the core collection were evaluated as surrogates for that resistance reaction type (Table 2). Information on Malus taxonomy for each species was obtained from the GRIN database, which adheres to the Malus systematics of Rehder (1915) and Langenfeld (1970).

\section{Orchard maintenance and weather data}

Malus accessions in the core collection are grafted on 'M9' rootstocks and are planted in 12 consecutive rows. The 12 rows are divided into 4 blocks (replications) with each replication arranged in 3 rows of trees. Accessions within each replicated block are planted using a randomized block design; in each block there is only one replicate of any accession (i.e., a single tree of each accession per block). Trees have $1.8 \mathrm{~m}$ in-row spacing and $3.9 \mathrm{~m}$ between-row spacing with a four-wire training system. Trees are approximately $15-20$ years old. No pesticides (i.e., insecticides, fungicides, and antibiotics) have been applied in the orchard since 2017 to avoid any possible pathogen, host and pesticide interactions and to observe pathogen isolates and host resistance responses under natural epidemic and selection environments. Trees were occasionally pruned, and a regular mowing schedule was maintained for laneways. The orchard was not fertilized or irrigated during the study period.

A Hobo RX3000 weather station equipped with temperature (Temp) and relative humidity (RH) sensors (Onset Computer Corporation, Bourne, MA) was located approximately $800 \mathrm{~m}$ east of the core collection research orchard and was used to collect weather 
Table 1 Apple scab resistance of accessions from a Malus core collection in a research orchard at Geneva, New York

\begin{tabular}{|c|c|c|c|c|c|}
\hline PI number & Name & Malus species & pi number & Name & $\begin{array}{l}\text { Malus } \\
\text { species }\end{array}$ \\
\hline \multicolumn{3}{|c|}{ Resistant } & \multicolumn{3}{|c|}{ Moderately susceptible } \\
\hline PI589763 & - & angustifolia & PI589820 & Prairie Fire & hybrid \\
\hline PI589838 & Hansen's \#2 & baccata & PI589819 & PRI 2050-2 & hybrid \\
\hline PI594110 & Jackii & baccata & PI588866 & Kerr & hybrid \\
\hline PI286599 & & baccata & PI589181 & Prima & hybrid \\
\hline PI589956 & $\begin{array}{l}\text { Antonovka 172670- } \\
\text { B }\end{array}$ & domestica & PI588991 & Bechtel Crab & ioensis \\
\hline PI590183 & Dayton & domestica & PI590015 & & ioensis \\
\hline PI588747 & Florina & domestica & PI589999 & & ioensis \\
\hline PI589962 & Jonafree & domestica & PI589932 & M0-84 & prunifolia \\
\hline PI594111 & Redfree & domestica & PI589390 & & sikkimensis \\
\hline PI589726 & Britegold & domestica & PI589420 & M. hartwigii & sp. \\
\hline PI588868 & - & florentina & PI589958 & MA \# 4 & toringo \\
\hline PI589933 & - & fusca & PI483254 & & $\mathrm{x}$ dawsoniana \\
\hline PI594105 & - & fusca & \multicolumn{3}{|c|}{ Susceptible } \\
\hline PI589972 & - & halliana & PI594099 & & asiatica \\
\hline PI589246 & Parkman & halliana & PI594107 & & asiatica \\
\hline PI594098 & - & hupehensis & PI437055 & Flexilis & baccata \\
\hline PI589522 & - & hupehensis & PI588930 & Macrocarpa & bhutanica \\
\hline PI588870 & Dolgo & hybrid & PI589170 & & brevipes \\
\hline PI589572 & E14-32 & hybrid & PI589976 & & coronaria \\
\hline PI590072 & E31-10 & hybrid & PI280400 & Anna & domestica \\
\hline PI590070 & E7-54 & hybrid & PI589596 & Calville Blanc & domestica \\
\hline PI589794 & PRI 1754-2 & hybrid & PI588848 & Cortland & domestica \\
\hline PI589807 & PRI 1773-6 & hybrid & PI588853 & $\begin{array}{l}\text { Cox's Orange } \\
\text { Pippin }\end{array}$ & domestica \\
\hline PI589792 & PRI 1850-4 & hybrid & PI589024 & Crimson Beauty & domestica \\
\hline PI589777 & PRI 1918-1 & hybrid & PI589841 & Delicious & domestica \\
\hline PI588992 & White Angel & hybrid & PI590179 & E. 8 & domestica \\
\hline PI589570 & E36-7 & hybrid & PI280401 & Ein Shemer & domestica \\
\hline PI590008 & - & ioensis & PI588842 & Empire & domestica \\
\hline PI594097 & - & kansuensis & PI588785 & $\begin{array}{l}\text { Esopus } \\
\text { Spitzenburg }\end{array}$ & domestica \\
\hline PI589955 & - & micromalus & PI392303 & Gala & domestica \\
\hline PI594096 & - & micromalus & PI590184 & Golden Delicious & domestica \\
\hline PI588933 & - & prattii & PI588880 & Granny Smith & domestica \\
\hline PI589832 & Xanthocarpa & prunifolia & PI589469 & Haralson & domestica \\
\hline PI594102 & - & prunifolia & PI588841 & Idared & domestica \\
\hline PI588761 & - & sargentii & PI589441 & Ingol & domestica \\
\hline PI594094 & - & toringo & PI589122 & $\begin{array}{l}\text { Kimball McIntosh } \\
2-4-4-4\end{array}$ & domestica \\
\hline PI589395 & - & tschonoskii & PI589053 & Lady & domestica \\
\hline PI588757 & - & $\mathrm{x}$ hartwigii & PI588998 & Marshall McIntosh & domestica \\
\hline PI588959 & - & $\begin{array}{l}\mathrm{x} \\
\text { magdeburgensis }\end{array}$ & PI589486 & Murray & domestica \\
\hline PI589415 & Hoopesii & x platycarpa & PI588872 & Northern Spy & domestica \\
\hline PI588825 & Robusta 5 & $\mathrm{x}$ robusta & PI589478 & $\begin{array}{l}\text { Novosibirski } \\
\text { Sweet }\end{array}$ & domestica \\
\hline \multicolumn{3}{|c|}{ Moderately resistant } & PI588798 & $\begin{array}{l}\text { Rambo-Red } \\
\text { Summer }\end{array}$ & domestica \\
\hline PI588960 & Rockii & baccata & PI589255 & Redspur Delicious & domestica \\
\hline PI322713 & Mandshurica 2330 & baccata & PI483257 & $\begin{array}{l}\text { Reinette } \\
\text { Simirenko }\end{array}$ & domestica \\
\hline PI588943 & Liberty & domestica & PI589520 & $\begin{array}{l}\text { Rhode Island } \\
\text { Greening }\end{array}$ & domestica \\
\hline PI589490 & Trent & domestica & PI588850 & Rome Beauty Law & domestica \\
\hline
\end{tabular}


Table 1 (continued)

\begin{tabular}{|c|c|c|c|c|c|}
\hline PI588806 & Chisel Jersey & domestica & PI589006 & Spokane Beauty & domestica \\
\hline PI107196 & $\begin{array}{l}\text { Antonovka } 1.5 \\
\text { pounds }\end{array}$ & domestica & PI588955 & Sweet Delicious & domestica \\
\hline PI588838 & Nova Easygro & domestica & PI589434 & Viking & domestica \\
\hline PI589975 & - & fusca & PI590186 & Wijcik McIntosh & domestica \\
\hline PI589941 & - & fusca & PI588778 & Virginiagold & domestica \\
\hline PI590071 & E29-56 & hybrid & PI589491 & $\begin{array}{l}\text { Korichnoe } \\
\text { Polosatoje }\end{array}$ & domestica \\
\hline PI590085 & PRI 1176-1 & hybrid & PI589913 & Dorsett Golden & domestica \\
\hline PI589812 & PRI 2377-1 & hybrid & PI589645 & Winter Majetin & domestica \\
\hline PI589790 & PRI 1484-1 & hybrid & PI588981 & Mollie's Delicious & domestica \\
\hline PI589775 & PRI 2382-1 & hybrid & PI589845 & Smith Jonathan & domestica \\
\hline PI589946 & PRI 1732-2 & hybrid & PI588772 & Monroe & domestica \\
\hline PI589795 & PRI 2482-100 & hybrid & PI246464 & $\begin{array}{l}\text { James Grieve (Red } \\
\text { Rosamund strain) }\end{array}$ & domestica \\
\hline PI589785 & PRI 1346-2 & hybrid & PI588844 & $\begin{array}{l}\text { Fuji Red Sport } \\
\text { Type } 2\end{array}$ & domestica \\
\hline PI589805 & Co-op 15 & hybrid & PI590185 & Jonathan & domestica \\
\hline PI588883 & Demir & hybrid & PI589827 & 821 & floribunda \\
\hline PI589776 & PRI 1316-1 & hybrid & PI589824 & Jonsib Crab & hybrid \\
\hline PI590069 & E7-47 & hybrid & PI589791 & PRI 1279-9 & hybrid \\
\hline PI588944 & Calva & kansuensis & PI589780 & PRI 384-1 & hybrid \\
\hline PI594092 & - & micromalus & PI589829 & PRI 333-9 & hybrid \\
\hline PI594095 & - & orientalis & PI589571 & E11-24 & hybrid \\
\hline PI589816 & 19651 & prunifolia & PI589786 & PRI 77-1 & hybrid \\
\hline PI589421 & M. rockii & sp. & PI588824 & Almey & hybrid \\
\hline PI589382 & - & sylvestris & PI590079 & PRI 1312-6 & hybrid \\
\hline PI369855 & - & sylvestris & PI588804 & Kansas K14 & hybrid \\
\hline PI589749 & - & toringo & PI589380 & & kirghisorum \\
\hline PI589384 & - & transitoria & PI590043 & & kirghisorum \\
\hline PI589003 & Korea & $\mathrm{x}$ robusta & PI588753 & & mandshurica \\
\hline PI271831 & Vilmorin & yunnanensis & PI589753 & & micromalus \\
\hline PI589758 & Veitchii & yunnanensis & PI594101 & & orientalis \\
\hline \multicolumn{3}{|c|}{ Moderately susceptible } & PI594109 & Microcarpa & prunifolia \\
\hline PI589727 & - & angustifolia & PI589930 & Nagano & prunifolia \\
\hline PI589869 & - & asiatica & PI594103 & Inuringo & prunifolia \\
\hline PI589393 & - & bhutanica & PI323617 & & pumila \\
\hline PI588995 & $\begin{array}{l}\text { Antonovka } \\
\text { Kamenichka }\end{array}$ & domestica & PI594106 & & pumila \\
\hline PI588835 & Burgundy & domestica & PI594104 & & sieversii \\
\hline PI589970 & Petrel & domestica & PI594100 & & spectabilis \\
\hline PI589894 & Keepsake & domestica & PI619168 & & sylvestris \\
\hline PI588859 & Yellow Transparent & domestica & PI589222 & Arnold Crab & $\mathrm{x}$ arnoldiana \\
\hline PI123989 & Emilia & domestica & PI589253 & Carmine Crab & $\begin{array}{l}\mathrm{x} \\
\text { atrosanguinea }\end{array}$ \\
\hline PI104727 & Irish Peach & domestica & PI589383 & Persicifolia & $\mathrm{x}$ robusta \\
\hline PI589648 & Rosemary Russet & domestica & PI589391 & & x soulardii \\
\hline PI588837 & $\begin{array}{l}\text { Gravenstein } \\
\text { Washington Red }\end{array}$ & domestica & PI588922 & $\begin{array}{l}\text { Yellow Autumn } \\
\text { Crab }\end{array}$ & x sublobata \\
\hline PI589789 & PRI 1744-1 & hybrid & PI590174 & Novole & x sublobata \\
\hline PI437057 & Roberts Crab & hybrid & PI589840 & Calocarpa & x zumi \\
\hline
\end{tabular}

Grouping of accessions into different classes is based on a visual assessment of the scab response type on visible leaves throughout the tree canopy on each tree in four replicated blocks and three sampling dates in 2018 and 2019. Assessments were based on an ordinal scale developed by Chevalier et al. (1991). Plant Introduction (PI) number of each accession is provided according to the USDA Germplasm Resources Information Network (GRIN)

data in 2018 and 2019. Temp and RH readings were collected at 5-min intervals and transmitted in real-time to the HOBO RX3000 base station, which uploaded data at 15 -min intervals to HOBOlink. Datasets were generated in HOBOlink for download, with hourly summarizations and subsequent analysis. Wet periods ( $\mathrm{RH}>90 \%)$ represented infection risk and were used to calculate Mills periods, based on the Temp and wet 
Table 2 Severity of apple scab at two timepoints in 2019 on a scab differential host set in the research orchard at Geneva, New York

\begin{tabular}{|c|c|c|c|c|c|}
\hline Differential host $^{a}$ & Host name & PI number & $R$ gene & $\begin{array}{l}\text { Severity (1-9, } \\
\text { July) }\end{array}$ & $\begin{array}{l}\text { Severity } \\
\text { (1-9, } \\
\text { August) }\end{array}$ \\
\hline ho & Gala & 392303 & - & 5 & 6 \\
\hline h1 & Golden Delicious & 590184 & Rvil & 7 & 7 \\
\hline h2 & TSR34t15 (syn. PRI 384-1) & 589780 & Rvi2 & 4 & 4 \\
\hline h3 & Malus × 'Geneva' & 589079 & Rvi3.1, Rvi3.2, Rvi3.3 & 3 & 4 \\
\hline h4 & TSR33t239 & $N / A^{b}$ & Rvi4 & 5 & 5 \\
\hline h5 & OR45T132 (syn. PRI 333-9) & 589829 & Rvi5 & 4 & 4 \\
\hline h6 & Priscilla & 589965 & Rvi6 & 1 & 1 \\
\hline h7 & Malus floribunda sel. 821 & 589827 & Rvi6, Rvi7 & $4^{c}$ & $4^{c}$ \\
\hline h9 & Malus $\times$ 'Dolgo' & 588870 & Rvi9, unknown & 4 & 4 \\
\hline h11 & Malus baccata 'jackii' & 594110 & Rvil1, unknown & 1 & 1 \\
\hline h12 & Malus baccata 'Hansens baccata \#2' & 589838 & Rvi12 & 1 & 1 \\
\hline
\end{tabular}

The scab severity within the tree canopy was visually assessed in four replicate trees of each accession using a 9 point scale described by Lateur and Populer (1994) and adapted by Patocchi et al. (2009), taking the most severely infected tree of each accession as the representative sample. These differential host accessions have known apple scab resistance genes (Bus et al. 2011) corresponding to specific races of $V$. inaequalis. Plant Introduction (PI) number of each accession is provided according to the USDA Germplasm Resources Information Network (GRIN)

a Differential apple hosts carrying specific Rvi scab resistance genes as described in Patocchi et al. (2020)

b Not available in the USDA-PGRU GRIN database

c Scab severity reported by Papp et al. (2019)

period duration according to MacHardy and Gadoury (1989).

\section{Assessment of apple scab symptoms}

Symptoms of apple scab on the 177 Malus accessions and the 10 differential apple host genotypes were evaluated three times a year in June, July, and August in 2018 and 2019. Evaluations consisted of a careful examination of the visible leaves in the tree canopy of each of the 177 trees and 10 differentials, in each of the 4 replicated blocks. The scab evaluations were used to ascertain the resistance response types of each of the accessions in the orchard, using a previously developed rank ordering of scab symptoms (Chevalier et al. 1991). The classes of the ordinal scale are as follows:

0-no symptoms; 1 -pin point pits; 2-chlorotic lesions; $3 \mathrm{a}-$ necrotic and some chlorotic lesions, very weak sporulation; $3 \mathrm{~b}-$ clearly sporulating chlorotic and necrotic lesions; and 4-abundantly sporulating lesions covering most of the leaf area. Based on the symptom classes we distinguished four response categories: 1Resistant (symptom class: $0,1,2), 2$-moderately resistant (3a), 3-Moderately susceptible (3b), 4-susceptible (4).

In addition, the 10 differential host accessions in the four replicated orchard blocks were evaluated for scab severity in early July and August of 2019. The most severely infected tree of each host accession in the four replicated blocks was used to represent the accession.
The scab severity within the tree canopy was visually evaluated using a 9 point ordinal scale described by Lateur and Populer (1994) and adapted by Patocchi et al. (2009): 0-no observation (missing plant); $1-$ no visible scab lesions; 2-one or very few scab lesions detectable on close scrutiny of the tree $(0-1 \%) ; 3-$ Immediately apparent scab lesions, generally clustered in a few parts of the tree (1-5\%); 4-intermediate; 5-numerous scab lesions widespread over a large proportion of the tree $( \pm 25 \%) ; 6$-intermediate; 7-severe symptoms of scab with half of the leaves severely scabbed exhibiting multiple lesions $( \pm 50 \%)$; 8 -intermediate $( \pm 75 \%)$; or 9-foliage of tree completely affected with (nearly) all the leaves severely diseased by multiple scab lesions $(>90 \%)$.

\section{Data analyses and visualization}

Statistical analyses were performed to evaluate the difference between the weather conditions of the 2 years, and to test differences in scab resistance of the accessions. The scab resistance reaction type data collected at three time points in 2018 and 2019 were used to assess scab susceptibility of each of the accessions. Scab resistance reaction type and severity data collected over 2 years for the differential hosts with ten known scab resistance genes were used to assess whether any local races of $V$. inaequalis were able to overcome the genetic resistance in hitherto resistant differentials and to identify novel sources of apple scab resistance. Results of daily RH and Temp data from April to October and scab 
resistance responses of accessions/Malus taxonomy groups for each species were visualized in $\mathrm{R}$ version 3.6.2 ( $\mathrm{R}$ Core Team 2020) using the inbuilt functions and the ggplot2 package (Wickham 2016). The effect of different genotypes and different time points within and across years on the disease severity inferred from the scab resistance reactions was explored using an ordinal logistic regression model in IBM SPSS Statistics v.25.0 (Arkmonk, NY). Furthermore, the total number of plants in each of the four categories of resistance response symptom classes for each month (June, July and August) in 2018 and 2019 and the corresponding weather variables were used to perform principal component analysis (PCA) analysis to study the effect of weather variables on disease susceptibility. The PCA results were explored graphically using biplots with the packages FactoMineR (Husson et al. 2020) and factoextra (Kassambara and Mundt 2017) in $\mathrm{R}$ version 3.6.2. Weather variables used included: average RH (RHave), minimum RH (RHmin), maximum RH (RHmax), average temperature (Tave), minimum temperature (Tmin), and maximum temperature (Tmax) for June, July and August 2018 and 2019. Pearson's correlation analysis among these variables was performed in $R$ version 3.6.2. A chi-square test was performed to evaluate relationship among Malus taxonomic groups and scab severity.

\section{Results}

Impact of weather conditions on apple scab severity In 2019, a higher proportion of the Malus core collection trees were infected with scab, which reached a plateau of approximately $50 \%$ of all the trees in the orchard, in contrast to 25\% in 2018 (Figs. 1 and 2). The ordinal logistic model showed significant $(P<0.0001)$ difference among the genotypes and the six timepoints in apple scab susceptibility. According to the dispersion of Mills periods across the two study years, 2019 experienced conditions favorable to infection by apple scab 2 weeks earlier (data not shown). During the early vegetative phase of growth, both average Temp and RH (\%) were higher in 2019 compared to in 2018 (Fig. 3). Later in the season, the relative difference in temperature between the 2 years shifted, but was close to the 16 to $23.9{ }^{\circ} \mathrm{C}$ optimum for scab development. The high Temp peaks in June and July of 2018 were $>32{ }^{\circ} \mathrm{C}$, higher than the more consistent daily temperatures experienced in 2019. The average monthly RH was higher in April, May, and July in 2019, and RH was $>90 \%$ more often throughout the whole season in 2019, providing more suitable conditions for spore germination of $V$. inaequalis.

The PCA biplot showed a strong positive association among RHave, RHmin and Tmin, and negative association between RHmax and Tmax (Fig. 4). The variables RHave and RHmin, RHave and Tmin, and RHmin and

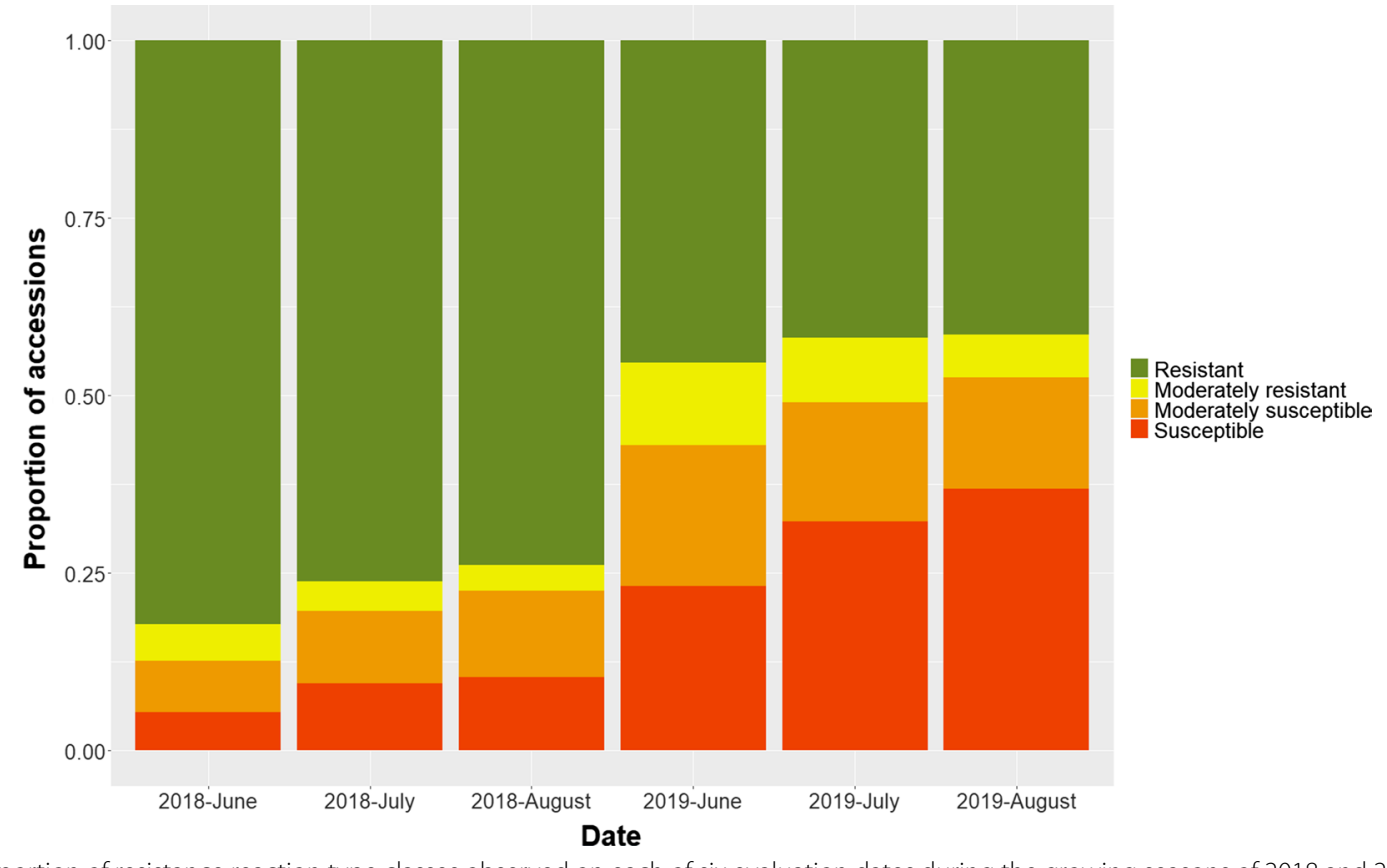

Fig. 1 Proportion of resistance reaction type classes observed on each of six evaluation dates during the growing seasons of 2018 and 2019 in the Malus germplasm core collection in the research orchard at Geneva, New York. Resistance categories were assessed as proposed by Chevalier et al. (1991). The orchard was not sprayed with pesticides 

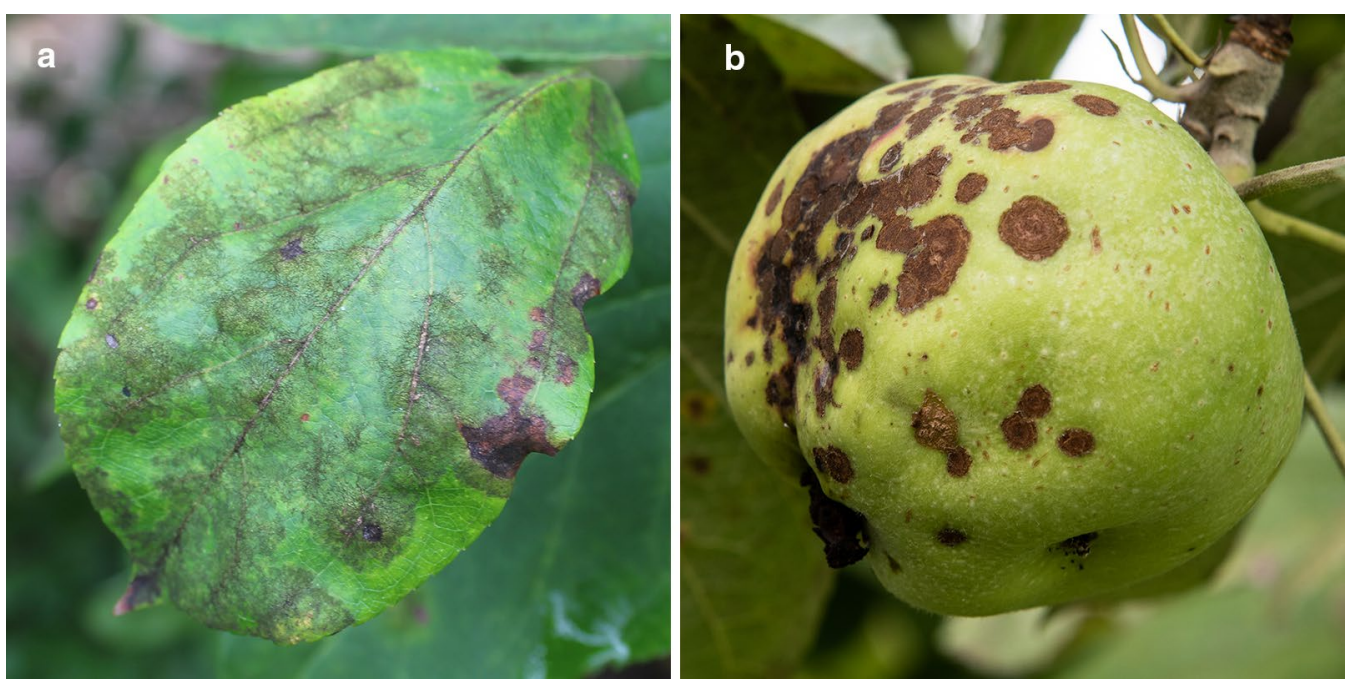

Fig. 2 Severe apple scab symptoms on 'Calville Blanc' apples (a) leaves and (b) fruit in the Malus core collection in the research orchard at Geneva, New York
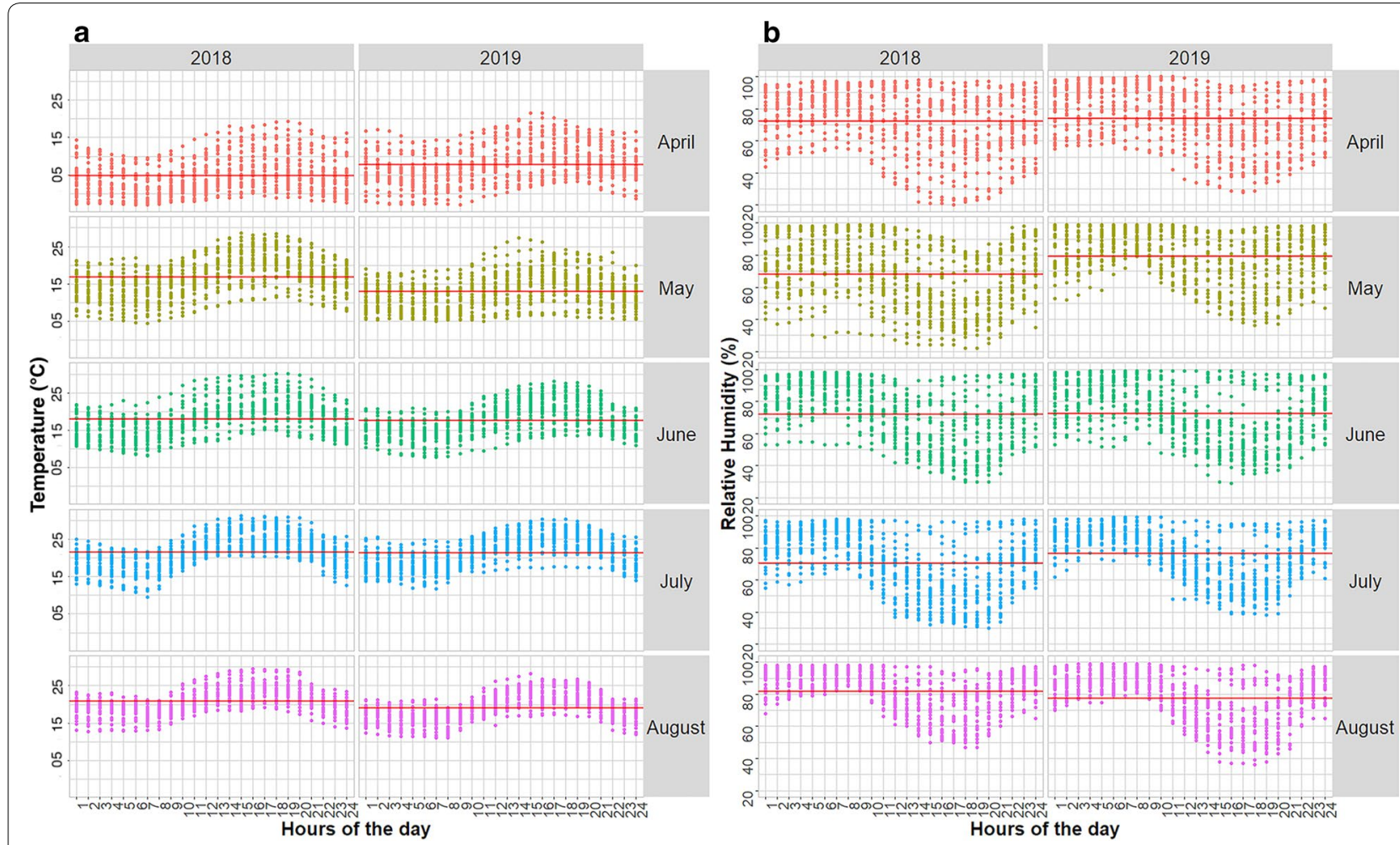

Fig. 3 Daily dispersion of $(\mathbf{a})$ temperature $\left({ }^{\circ} \mathrm{C}\right)$ and $(\mathbf{b})$ relative humidity $(\%)$ from April to August in 2018-2019, at the same location as the Malus germplasm core collection at Geneva, New York. Different colors indicate different months. The red line shows (a) the mean temperature, and (b) the mean relative humidity for each of the months

Tmin showed positive correlations ( $\mathrm{r}$ ) of $0.96,0.86$ and 0.93, respectively, whereas RHmax and Tmax showed a negative correlation $(r)$ of -0.61 . The first two PCs (principal components) explained $86.6 \%$ of the variation; PC1 and PC2 explained $53.6 \%$ and $33 \%$ of the variation, respectively. Apple scab susceptibility was found to be 


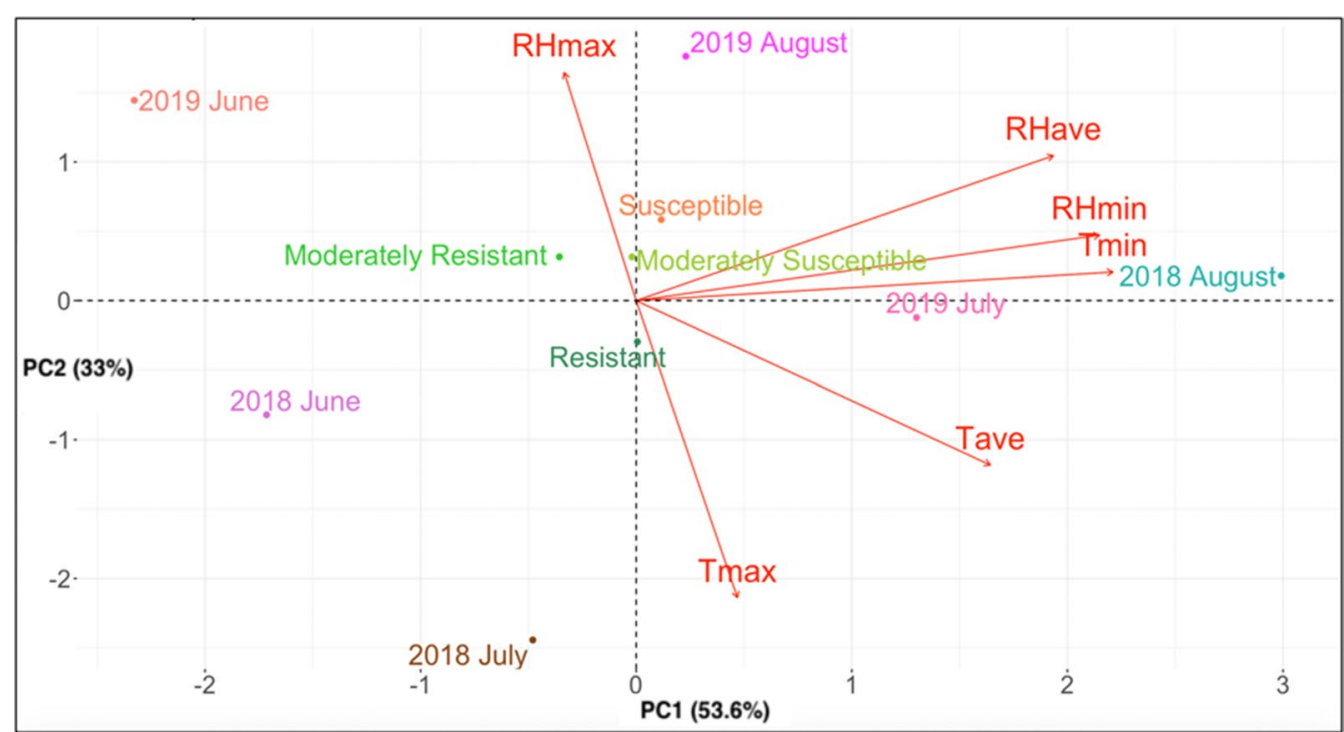

Fig. 4 PCA biplot showing PC1 and PC2 to depict the relationship between different weather parameters and apple scab severity (resistance reaction type) for the six dates when scab was evaluated. The number of plants in the Malus germplasm core collection in each of four categories of symptom classes: Resistant, Moderately resistant, Moderately susceptible, and Susceptible were counted in June, July and August of 2018 and 2019 , and used to perform principal component analysis (PCA) using the package FactoMineR (Husson et al. 2020) and factoextra (Kassambara and Mundt 2017) in R version 3.6.2 (R Core Team 2020). Weather variables are: average relative humidity (RHave), minimum relative humidity (RHmin), maximum relative humidity (RHmax), average temperature (Tave), minimum temperature (Tmin), and maximum temperature (Tmax)

influenced by RHmax, RHave, RHmin and Tmin, whereas apple scab resistance was found to be influenced by Tmax as depicted by the location of RHmax in relation to the moderately susceptible accessions, RHave, RHmin, Tmin, and the susceptible accessions, and Tmax and the resistant accessions in the same quadrant of the PCA biplot i.e. quadrant II, I and IV of the PCA biplot, respectively. The presence of RHmax and susceptible accessions, and Tmax and resistant accessions in close proximity to each other in the PCA biplot shows strong association of RHmax and scab symptom development, and Tmax and disease resistance respectively (Fig. 4).

\section{Scab severity on the differential set}

The indicator accessions with ten known scab resistance genes were used to monitor the severity of scab infection in relation to races of $V$. inaequalis present in the orchard (Table 2). 'Gala' showed heavy scab infection in both years. Scab severity on 'Golden Delicious', carrying Rvi1, was even higher (class 7) compared to severity on the susceptible control. Differential hosts 2 (TSR34t15), 3 (M. × 'Geneva'), 4 (TSR33t239), 5 (OR45T132) and $9(M . \times$ 'Dolgo') were all severely diseased with scab, indicating the presence of races 1 to 5 and race 9. Scab severity was as high as class 4 , except for host differential indicator for race 4 , which was rated in scab severity class 5 by the end of the season. M. baccata 'Jackii' (indicator for race 11) and 'Hansens baccata \#2' (indicator for race
12) were free of scab. Severe scab was observed on $M$. floribunda 821, the source of Rvi6 and Rvi7 resistance, as reported earlier by Papp et al. (2019), but 'Priscilla' (Rvi6) was free of scab symptoms. Overall, resistance response types were consistent over the period of assessment, with only slight differences in severity.

\section{Sources of novel scab genetic resistance in the core collection}

Of the 177 Malus accessions evaluated for apple scab symptom, a total of $49,17,32$, and 79 accessions were free of scab or resistant (ordinal scale classes $0,1,2$ ), had weak sporulation (3a), had well-developed sporulating lesions (3b), or were completely susceptible (4), respectively (Table 1; Additional file 1: Table S1). The 49 resistant accessions are mostly primary Malus species (46.9\%), hybrids from breeding programs (22.4\%), secondary Malus sp. (14.3\%), and Rvi6 resistant cultivars (12.2\%); there were two apple 'Antonovka' landraces (4\%). In contrast to the large number of resistant accessions among the primary apple species, no modern domestic cultivar lacking a known major resistance gene was found to be completely free of scab. In the most susceptible category $(\mathrm{n}=79), 51.8 \%$ were domestic cultivars. Out of $61 \mathrm{M}$. domestica accessions included in the study, 8 were resistant to apple scab ('Antonovka 172670-B', 'Antonovka 43470 lb', 'Britegold, 'Dayton, 'Florina', 'Jonafree', 'Liberty', and 'Redfree'). Most of these accessions with scab 
resistant phenotypes can be traced back to PRI breeding materials and are considered to have Rvi6 resistance from $M$. floribunda 821. Sporulation of scab lesions was noticed on Rvi6 cultivars 'Prima' and 'Nova Easygro' and has been reported previously (Papp et al. 2019). In addition, PRI cultivars 'Murray' (Rvi5), 'Trent' (Rvi6) and 'Viking' were found to show scab symptoms. Only 5 of the 19 hybrid selections listed by their PRI codes did not show symptoms during the 2 years. The selections PRI 333-9 (syn. OR45T132, Rvi5) and PRI 384-1 (syn. TSR34T15, Rvi2) were both severely scabbed. Besides the PRI derivates, two cultivars: 'Demir' and 'Chisel Jersey', were evaluated as moderately resistant to scab. Traditional heritage cultivars including 'Gravenstein Washington Red' and 'Irish Peach', or 'Burgundy' had less severe symptoms compared to 'McIntosh', 'Granny Smith', 'Gala', or 'Golden Delicious'.

The highest number of scab infected accessions are in the Malus section. In August 2019, scab severity was the highest in the Malus section at all time points; approximately $81 \%$ of the genotypes in the Malus section showed scab susceptibility (Additional file 1: Table S1). The percentage of scabbed genotypes for the interspecific hybrids was approximately $41 \%$, and for the sections Chloromeles, Gymnomeles, and Sorbomalus was $35 \%, 28 \%$, and $18 \%$ of trees, respectively (Fig. 5). No completely susceptible accession was identified in the sections Sorbomalus and Dyconiopsis. However, the section Dyconiopsis, comprised only one accession with 3 samples, which showed moderate susceptibility in 2018, but not in 2019. Scab resistance differed significantly among six taxonomic groups $\left(\chi^{2}{ }_{(\text {d.f. } 4)}=40.365\right.$, $p<0.001)$. Although the proportion of trees with apple scab increased from 2018 to 2019, this did not affect the relative differences between the scab susceptibilities of the taxonomic groups.

\section{Discussion}

Detailed and systematic screening of diverse Malus germplasm can identify donor accessions for sources of novel and durable apple scab resistance. We have identified potential new sources of scab resistance among $M$.

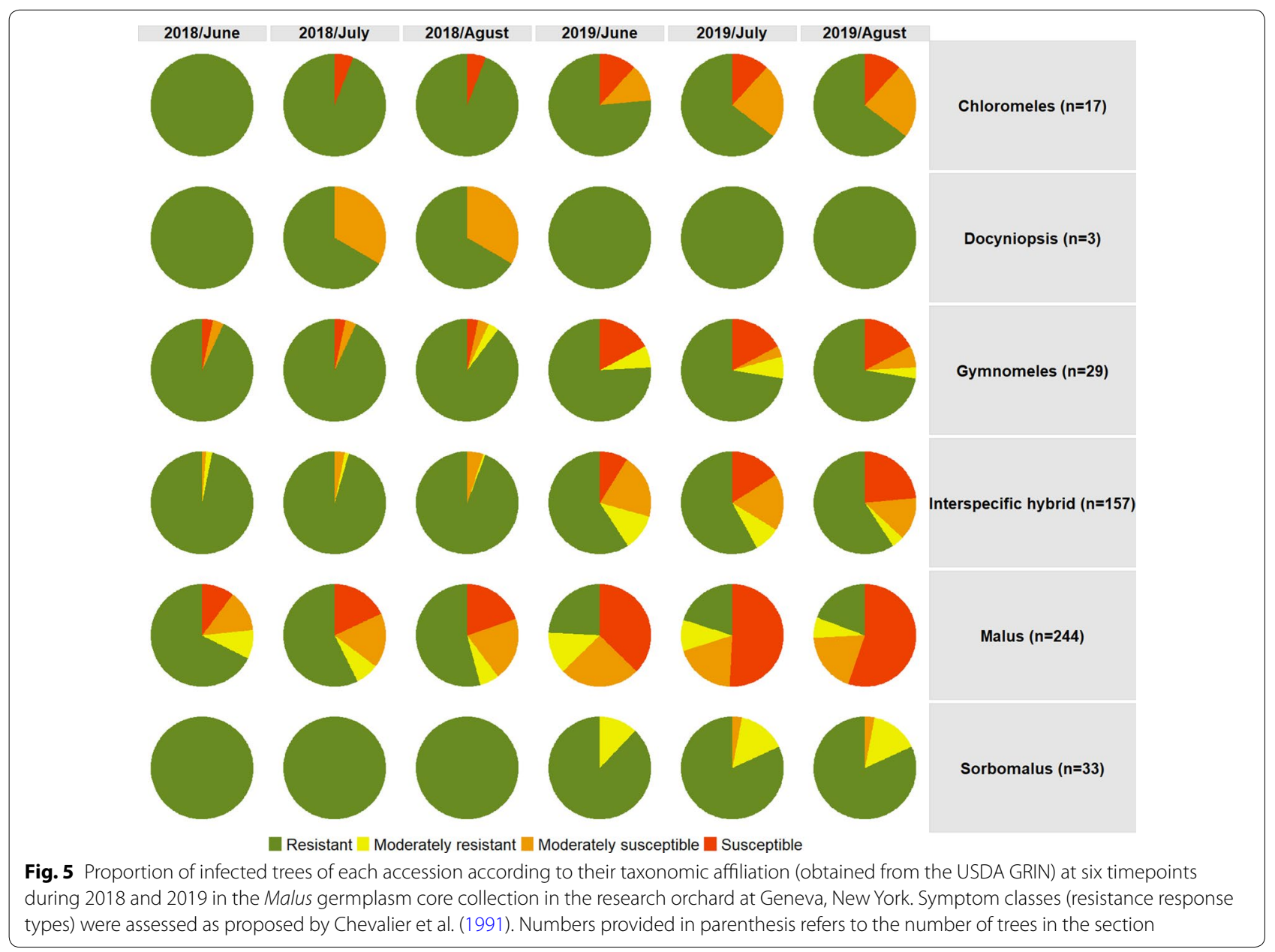


domestica cultivars and crabapples. Resistant and moderately resistant accessions are promising for use in future genetic studies to identify novel sources of scab resistant alleles for apple breeding (Patocchi et al. 2020; Papp et al. 2019). Domestic cultivars 'Demir' and 'Chisel Jersey' were moderately resistant. Although occasional weak sporulation was observed on some of the trees, the sporulation was slight and the severity low enough to preclude posing any economic threat to production. In addition, we noticed that both 'Demir' and 'Chisel Jersey' are late season and there is the possibility that they escaped a high-risk infection period. 'Demir' is a Turkish fresh eating cultivar, while 'Chisel Jersey' is a cider cultivar from the United Kingdom (UK). Many of the crabapples with unknown resistance were free of scab, including accessions of unknown hybrid species, breeding materials and Malus species. The majority of $R$ genes are derived from small-fruited crabapples: Rvi2 and Rvi4 from M. pumila R12740-7A, Rvi5 from M. $\times$ atrosanguinea Schneid. sel. 804 and M. micromalus 245-38, Rvi6 and Rvi7 from $M$. floribunda 821, Rvi8 from M. sieversii GMAL4302-X8, Rvi11 from M. baccata 'jackii', Rvi12 from M. baccata 'Hansen's 2\#' and Rvi9 from M. × 'Dolgo', possibly a clone of M. baccata or M. prunifolia (Willd.) Borkh. (Bus et al. 2011). We lack molecular and genomic data to characterize the genetic basis of the resistance of many of these promising accessions, although it is possible that these resistances were due to already-described major genes or by polygenic quantitative resistance. Novel single genebased resistance can be easier to characterize and provide new opportunities for apple breeding. At the same time new technologies including biotechnology, genomics, marker assisted selection and novel breeding methods might make polygenic resistance sources more accessible and reliable for apple breeding in the future.

We observed the breakdown of major resistance genes Rvi1 to Rvi7 and Rvi9 in the research orchard. The $V$. inaequalis races 1, 7 and 9 have all been reported previously from the U.S.A. (Beckerman et al. 2009; Durham et al. 1999; Papp et al. 2019; Shay and Williams 1956; Williams and Kuc 1969). No scab was observed on the differentials of race 11 and 12, although of these, only host 11 (alongside the host for race 15, which was not included in the study) were assigned as 'not overcome' by a recent update on worldwide race distributions (Patocchi et al. 2020). In the case of hosts for races 2 (PRI 384-1) and 5 (PRI 333-9, 'Murray', Malus sp. 'Prairie Fire'), all other genotypes screened that possessed known $R$ genes have confirmed breakdown; in the case of Rvi6, many cultivars remained resistant (e.g. 'Liberty', 'Florina'). It should be noted that the only apple cultivars with good fruit quality, and that have scab resistance are those with the Rvi6 gene. We do not yet know why Rvi6 cultivars retain their resistance when the original host source of the Rvi6 resistance can be infected by $V$. inaequalis. Investigating the reason why infection of Malus floribunda 821, the source of Rvi6 resistance, is possible, but infection of descendant cultivars is not will be of value for informed development of scab resistant cultivars in the future.

In our study, we have identified a clear relationship between the taxonomic affiliation and the scab susceptibility of Malus germplasm. The relationship might reflect host frequency-based selection on the pathogen, hypothesizing that scab susceptibility of wild species is directly related to their genetic proximity to the domesticated apple. The domestication of apples started in Central Asia, where the primary progenitor, $M$. sieversii exists in large natural populations. Congruent with this host distribution, $V$. inaequalis populations infecting domesticated apples originated from Central Asia and coevolved with $M$. sieversii during the domestication process (Gladieux et al. 2008, 2010). Populations of the pathogen tend to show distinct genetic structure related to their original Malus host species, and the breakdown of resistance genes derived from wild Malus species might be caused by divergent pathogen populations emerging from wild apple reservoirs, as has been demonstrated in the case of Rvi6 resistance (Gladieux et al. 2010; Lemaire et al. 2016; Leroy et al. 2016; Michalecka et al. 2018). M. sieversii accessions (including the accession of $M$. kirghisorum syn. M. sieverii var. kirghisorum) were susceptible to apple scab in our study. There is substantial genetic evidence that the European wild apple $M$. sylvestris, $M$. orientalis with gene centers to the west of Central Asia, as well as M. baccata with gene centers in East Asia, have hybridized with domestic apple during the domestication process (Cornille et al. 2012, 2014; Duan et al. 2017; Volk et al. 2015b). Overall, accessions of $M$. domestica and $M$. sieversii, two closely related species, had considerably more severe scab compared to the accessions of the other wild Malus species. Despite this finding, the inoculum of $V$. inaequalis from the Malus core collection research orchard might simply not be diverse enough to reflect larger scale trends and might represent races specialized to domestic cultivars. Larger-scale genetic studies and genome-based analysis of local isolates will contribute to understanding the pathogen in relation to host specificity patterns in the Malus-Venturia pathosystem.

A consequence of modern production systems with large acreage of monocultures could facilitate specialization of pathogen strains on particular cultivars, the build-up of large populations on uniform host populations with rapid dissemination of the new strain (McDonald and Stukenbrock 2016). The sexual and asexual phases of $V$. inaequalis can allow it to evolve rapidly and in the context of modern high-density 
apple orchards, it has the ability to quickly overcome genetic resistance in apples. Therefore, it is critical to continue to identify and characterize new sources of both qualitative and quantitative scab resistance and pyramid multiple resistance sources in order to develop apple cultivars with durable scab resistance. The scab resistance screening data from this study can be combined with previous assessments for fire blight resistance, fruit quality, and horticultural traits (Khan et al. 2013; Luby et al. 1996; Potts et al. 2012) available for the majority of the accessions in the Malus core collection to identify potential sources for introgression of multiple traits for cultivar development. At the same time, it is also important to understand the relationship between the evolutionary potential of $V$. inaequalis and current disease management practices for enhancing the durability of the resistance genes. Disease management practices to decrease population sizes of the pathogen, limiting production of sexual inoculum, may also contribute to reducing the pathogen's evolutionary potential (McDonald 2015).

\section{Supplementary information}

Supplementary information accompanies this paper at https://doi. org/10.1186/s43170-020-00017-4.

Additional file 1: Table S1. Apple scab resistance response type of 177 Malus accessions in four blocks (replications) across six sampling dates in 2018 and 2019. Resistance response type was evaluated in a research orchard at Geneva, New York by visually assessing scab severity on single leaves throughout the visible tree canopy of single trees/accessions in each replicated block. Plant Introduction (PI) number of each accession is provided according to the USDA Germplasm Resources Information Network (GRIN)

\section{Acknowledgments}

Not applicable.

\section{Authors' contributions}

AK designed the experiment, supervised the research and revised the manuscript. DP and LG collected the apple scab data in 2018 and 2019 respectively. DP analyzed the data and wrote the manuscript, RT helped with statistical analysis, DO supported weather data collection. All authors read and approved the manuscript.

\section{Funding}

This research was supported by the New York Apple Research and Development Program (ARDP). David Papp is supported by the Miklos Faust scholarship in fruit science.

\section{Availability of data and materials \\ Not applicable.}

Ethics approval and consent to participate

Not applicable.

\section{Competing interests}

The authors declare that they have no competing interests.

\section{Author details}

${ }_{1}^{1}$ Plant Pathology and Plant-Microbe Biology Section, Cornell University, Geneva, NY 14456, USA. ${ }^{2}$ College of Plant Protection, Northwest A\&F University, Yangling 712100, Shaanxi, China. ${ }^{3}$ New York State Integrated Pest Management Program, Cornell University, Geneva, NY 14456, USA.

Received: 19 June 2020 Accepted: 9 October 2020

Published online: 28 October 2020

\section{References}

Aldwinckle HS, Forsline PL, Gustafson HL, Hokanson SC. Evaluation of apple scab resistance of Malus sieversii populations from Central Asia. HortScience. 1997;32:440.

Beckerman J, Chatfield J, Draper E. A 33-year Evaluation of resistance and pathogenicity in the apple scab-crabapples pathosystem. HortScience. 2009;44(3):599-608.

Brown S, Maloney K. Scab-resistant cultivars (varieties). N Y Fruit Q. 2008;16(4):3-6.

Brown SK, Maloney KE. An update on apple cultivars, brands and club-marketing. N Y Fruit Q. 2013;21(1):3-10.

Bus VG, Rikkerink EH, Caffier V, Durel CE, Plummer KM. Revision of the nomenclature of the differential host-pathogen interactions of Venturia inaequalis and Malus. Annu Rev Phytopathol. 2011;49:391-413.

Byrne PF, Volk GM, Gardner C, Gore MA, Simon PW, Smith S. Sustaining the future of plant breeding: the critical role of the USDA-ARS National Plant Germplasm System. Crop Sci. 2018;58(2):451-68.

Chevalier M, Lespinasse Y, Renaudin S. A microscopic study of the different classes of symptoms coded by the $\mathrm{Vf}$ gene in apple for resistance to scab (Venturia inaequalis). Plant Pathol. 1991;40(2):249-56.

Cornille A, Gladieux P, Smulders MJ, Roldán-Ruiz I, Laurens F, Le Cam B, Nersesyan A, Clavel J, Olonova M, Feugey L, Gabrielyan I, Zhang XG, Tenaillon MI, Giraud T. New insight into the history of domesticated apple: secondary contribution of the European wild apple to the genome of cultivated varieties. PLoS Genet. 2012;8(5):e1002703.

Cornille A, Giraud T, Smulders MJ, Roldán-Ruiz I, Gladieux P. The domestication and evolutionary ecology of apples. Trends Genet. 2014;30(2):57-65.

Crosby JA, Janick J, Pecknold PC, Korban SS, O'Conner PA, Ries SM, Goffreda J, Voordeckers A. Breeding apples for scab resistance: 1945-1990. Fruit Breed Genet. 1992;317:43-70.

Duan N, Bai Y, Sun H, Wang N, Ma Y, Li M, Wang X, Jiao C, Legall N, Mao L, Wan S. Genome re-sequencing reveals the history of apple and supports a two-stage model for fruit enlargement. Nat Commun. 2017;8(1):249.

Durham RE, McNeil RE, Hartman JR, Potter DA, Fountain WM. The flowering crabapple. Univ. of Kentucky, Coop. Ext. Svc. Pub. ID-68. 1999.

Escribano P, Viruel MA, Hormaza Jl. Comparison of different methods to construct a core germplasm collection in woody perennial species with simple sequence repeat markers. A case study in cherimoya (Annona cherimola, Annonaceae), an underutilised subtropical fruit tree species. Ann Appl Biol. 2008;153:25-32.

Forsline PL, Aldwinckle HS. Natural occurrence of fire blight in USDA apple germplasm collection after 10 years of observation. In: IX international workshop on fire blight, vol. 590. 2001. p. 351-7.

Forsline PL, Aldwinckle HS. Evaluation of Malus sieversii seedling populations for disease resistance and horticultural traits. In: XI eucarpia symposium on fruit breeding and genetics, vol. 663. 2003. p. 529-34.

Francl $\sqcup$. The disease triangle: a plant pathological paradigm revisited. Plant Health Instr. 2001. https://doi.org/10.1094/PHI-T-2001-0517-01.

Girichev V, von Reth M, Hanke MV, Höfer M, Schulte E, Flachowsky H. Evaluation of Rubus genetic resources on their resistance to cane disease. Genet Resour Crop Evol. 2018;65(7):1979-93.

Gladieux P, Zhang XG, Afoufa-Bastien D, Sanhueza RMV, Sbaghi M, Le Cam B. On the origin and spread of the scab disease of apple: out of central Asia. PLOS ONE. 2008;3(1):1455

Gladieux P, Zhang XG, Roldan-Ruiz I, Caffier V, Leroy T, Devaux M, van Glabeke $S$, Coart E, Le Cam B. Evolution of the population structure of Venturia inaequalis, the apple scab fungus, associated with the domestication of its host. Mol Ecol. 2010;19(4):658-74. 
González-Domínguez E, Armengol J, Rossi V. Biology and epidemiology of Venturia species affecting fruit crops: a review. Front Plant Sci. 2017:8:1496. https://doi.org/10.3389/fpls.2017.01496.

Hagan AK, Tilt KM, Williams JD, Akridge JR. Susceptibility of crabapple cultivars to several diseases in the Gulf Coast region of Alabama. J Environ Hortic. 2000;18(4):192-6.

Harshman JM, Evans KM, Allen H, Potts R, Flamenco J, Aldwinckle HS, Wisniewski NE, Norelli JL. Fire blight resistance in wild accessions of Malus sieversii. Plant Dis. 2017:101(10):1738-45.

Hokanson SC, McFerson JR, Forsline PL, Lamboy WF, Luby JJ, Aldwinckle HS, Djangaliev AD. Collecting and managing wild Malus germplasm in its center of diversity. HortScience. 1997;32:173-6.

Hokanson SC, Lamboy WF, Szewc-McFadden AK, McFerson JR. Microsatellite (SSR) variation in a collection of Malus (apple) species and hybrids. Euphytica. 2001;118(3):281-94.

Husson F, Josse J, Le S, Mazet J, Husson MF. Package "FactoMineR". 2020. https://cran.r-project.org/web/packages/FactoMineR/index.html.

Jänsch M, Paris R, Amoako-Andoh F, Keulemans W, Davey MW, Pagliarani G, Tartarini S, Patocchi A. A phenotypic, molecular and biochemical characterization of the first cisgenic scab-resistant apple variety 'Gala! Plant Mol Biol Rep. 2014;32(3):679-90.

Jurick WM, Janisiewicz WJ, Saftner RA, Vico I, Gaskins VL, Park E, Forsline PL, Fazio G, Conway WS. Identification of wild apple germplasm (Malus spp.) accessions with resistance to the postharvest decay pathogens Penicillium expansum and Colletotrichum acutatum. Plant Breed. 2011;130(4):481-6.

Kassambara A, Mundt F. Factoextra: extract and visualize the results of multivariate data analyses. R Package Version. 2017;1(4):2017.

Kellerhals M, Bertschinger L, Gessler C. Use of genetic resources in apple breeding and for sustainable fruit production. J Fruit Ornamental Plant Res. 2004;12:53-62.

Khajuria YP, Kaul S, Wani AA, Dhar MK. Genetics of resistance in apple against Venturia inaequalis (Wint.) Cke. Tree Genet Genomes. 2018;14(2):16.

Khan MA, Chao T. Wild apple species as a source of fire blight resistance for sustainable productivity of apple orchards. N York Fruit Q. 2017;25(4):13-8.

Khan MA, Zhao Y, Korban SS. Identification of genetic loci associated with fire blight resistance in Malus through combined use of QTL and association mapping. Physiol Plant. 2013;148(3):344-53.

Koutis K, Francois W, Nicolaus B, Steinemann B, Rodriguez Buruezzo A, Mendes Moreira P, Messmer M Perspectives on European organic apple breeding and propagation under the frame of LIVESEED Project. In: Proceedings of the 18th international conference on organic fruitgrowing, 19-21 February 2018. Hohenheim, Germany, 2018; pp. 104-7.

Langenfeld VT. Malus Mill.: Biology, Geography, Systematics, Phylogeny, Evolution (in Russian). Rija Zinatne. 1970; p.1-203.

Lateur M, Populer C. Screening fruit tree genetic resources in Belgium for disease resistance and other desirable characters. Euphytica. 1994;77(1-2):147-53.

Lemaire C, De Gracia M, Leroy T, Michalecka M, Lindhard-Pedersen H, Guerin F, Gladieux P, Le Cam B. Emergence of new virulent populations of apple scab from nonagricultural disease reservoirs. New Phytol. 2016;209(3):1220-9.

Leroy T, Caffier V, Celton JM, Anger N, Durel CE, Lemaire C, Le Cam B. When virulence originates from nonagricultural hosts: evolutionary and epidemiological consequences of introgressions following secondary contacts in Venturia inaequalis. New Phytol. 2016;210(4):1443-52.

Liang W, Dondini L, De Franceschi P, Paris R, Sansavini S, Tartarini S. Genetic diversity, population structure and construction of a core collection of apple cultivars from Italian germplasm. Plant Mol Biol Rep. 2015;33(3):458-73.

Luby J, Hoover E, Peterson M, Larson D, Bedford D. Cold hardiness in the USDA Malus core germplasm collection. In: Eucarpia symposium on fruit breeding and genetics, vol. 484. 1996. p. 109-14.

Luby JJ, Alspach PA, Bus VG, Oraguzie NC. Field resistance to fire blight in a diverse apple (Malus sp.) germplasm collection. J Am Soc Hortic Sci. 2002;127(2):245-53.

MacHardy WE, Gadoury DM. A revision of Mills's criteria for predicting apple scab infection periods. Phytopathology. 1989;79(3):304-10.
MacHardy WE, Gadoury DM, Gessler C. Parasitic and biological fitness of Venturia inaequalis: relationship to disease management strategies. Plant Dis. 2001;85(10):1036-51.

McDonald BA. How can research on pathogen population biology suggest disease management strategies? The example of barley scald (Rhynchosporium commune). Plant Pathol. 2015;64(5):1005-13.

McDonald BA, Stukenbrock EH. Rapid emergence of pathogens in agroecosystems: global threats to agricultural sustainability and food security. Philos Trans R Soc B Biol Sci. 2016;371(1709):20160026.

Michalecka M, Masny S, Leroy T, Puławska J. Population structure of Venturia inaequalis, a causal agent of apple scab, in response to heterogeneous apple tree cultivation. BMC Evol Biol. 2018;18(1):5.

Momol MT, Forsline PL, Lamboy WF, Aldwinckle HS. Fire blight resistance and horticultural evaluation of wild Malus populations from Central Asia. Acta Hort. 1999;489:229-34.

Myers CT, Harvey Reissig W, Forsline PL. Susceptibility of fruit from diverse apple and crabapple germplasm to attack from apple maggot (Diptera: Tephritidae). J Econ Entomol. 2008;101(1):206-15.

Norelli JL, Wisniewski M, Droby S. Identification of a QTL for postharvest disease resistance to Penicillium expansum in Malus sieversii. In: II international symposium on discovery and development of innovative strategies for postharvest disease management, vol. 1053. 2013. p. 199-203.

Papp D, Singh J, Gadoury DM, Khan MA. New North American isolates of Venturia inaequalis can overcome apple scab resistance of Malus floribunda 821. Plant Dis. 2019;104(3):649-55.

Parisi L, Lespinasse Y, Guillaumes J, Krüger J. A new race of Venturia inaequalis virulent to apples with resistance due to the Vf gene. Phytopathology. 1993;83(5):533-7.

Parisi L, Fouillet V, Schouten HJ, Groenwold R, Laurens F, Didelot F, Evans K Fischer C, Gennari F, Kemp H, Lateur M, Patocchi A, Thissen J, Tsipouridis C. Variability of the pathogenicity of Venturia inaequalis in Europe. Acta Hort. 2004;663(1):107-13.

Patocchi A, Frei A, Frey JE, Kellerhals M. Towards improvement of marker assisted selection of apple scab resistant cultivars: Venturia inaequalis virulence surveys and standardization of molecular marker alleles associated with resistance genes. Mol Breed. 2009;24(4):337.

Patocchi A, Wehrli A, Dubuis P-H, Auwerkerken A, Leida C, Cipriani G, Passey T, Staples M, Didelot F, Philion V, Peil A, Laszakovits H, Rühmer T, Boeck K, Baniulis D, Strasser K, Vávra R, Guerra W, Masny S, Ruess F, Le Berre F, Nybom H, Tartarini S, Spornberger A, Pikunova A, Bus V. Ten years of VINQUEST: first insight for breeding new apple cultivars with durable apple scab resistance. Plant Dis. 2020;104(8):2074-81.

Peck GM, Merwin IA, Brown MG, Agnello AM. Integrated and organic fruit production systems for 'Liberty'apple in the Northeast United States: a systems-based evaluation. HortScience. 2010;45(7):1038-48.

Potts SM, Han Y, Khan MA, Kushad MM, Rayburn AL, Korban SS. Genetic diversity and characterization of a core collection of Malus germplasm using simple sequence repeats (SSRs). Plant Mol Biol Rep. 2012;30(4):827-37.

$R$ Core Team. R: a language and environment for statistical computing. Vienna: R Foundation for Statistical Computing; 2020.

Rehder A. Rosaceae. Subfam. Pomoideae. In: Sargent CS, editor. Plantae Wilsonianae 2. Publications of the Arnold Arboretum, Cambridge (Mass.), vol. 4. 1915. p. 263-345.

Schoen DJ, Brown AHD. Maximising genetic diversity in core collections of wild relatives of crop species. In: Hodgkin T, Brown AHD, van Hintum TJL, Morales EAV, editors. Core collections of plant genetic resources. Chichester: Wiley; 1995. p. 55-76.

Schouten HJ, Brinkhuis J, van der Burgh A, Schaart JG, Groenwold R, Broggini GA, Gessler C. Cloning and functional characterization of the Rvi15 (Vr2) gene for apple scab resistance. Tree Genet Genomes. 2014;10(2):251-60.

Shay JR, Williams EB. Identification of three physiologic races of Venturia inaequalis. Phytopathology. 1956;46:190-3.

Vasudevan K, Vera Cruz CM, Gruissem W, Bhullar NK. Large scale germplasm screening for identification of novel rice blast resistance sources. Front Plant Sci. 2014;5:505.

Volk GM, Richards CM, Reilley AA, Henk AD, Forsline PL, Aldwinckle HS. Ex situ conservation of vegetatively propagated species: development of a seed-based core collection for Malus sieversii. J Am Soc Hortic Sci. 2005;130(2):203-10. 
Volk GM, Richards CM, Reilley AA, Henk AD, Reeves PA, Forsline PL, Aldwinckle $\mathrm{HS}$. Genetic diversity and disease resistance of wild Malus orientalis from Turkey and Southern Russia. J Am Soc Hortic Sci. 2008;133(3):383-9.

Volk GM, Chao CT, Norelli J, Brown SK, Fazio G, Peace C, McFerson J, Zhong GY, Bretting P. The vulnerability of US apple (Malus) genetic resources. Genet Resour Crop Evol. 2015a;62:765-94.

Volk GM, Henk AD, Baldo A, Fazio G, Chao CT, Richards CM. Chloroplast heterogeneity and historical admixture within the genus Malus. Am J Bot. 2015b:102(7):1198-208

Wickham H. ggplot2: elegant graphics for data analysis. Berlin: Springer; 2016.
Williams EB, Kuc J. Resistance in Malus to Venturia inaequalis. Annu Rev Phytopathol. 1969;7(1):223-46.

Xu X, Yang J, Thakur V, Roberts A, Barbara DJ. Population variation of apple scab (Venturia inaequalis) isolates from Asia and Europe. Plant Dis. 2008;92(2):247-52.

\section{Publisher's Note}

Springer Nature remains neutral with regard to jurisdictional claims in published maps and institutional affiliations.
Ready to submit your research? Choose BMC and benefit from:

- fast, convenient online submission

- thorough peer review by experienced researchers in your field

- rapid publication on acceptance

- support for research data, including large and complex data types

- gold Open Access which fosters wider collaboration and increased citations

- maximum visibility for your research: over $100 \mathrm{M}$ website views per year

At BMC, research is always in progress.

Learn more biomedcentral.com/submissions 